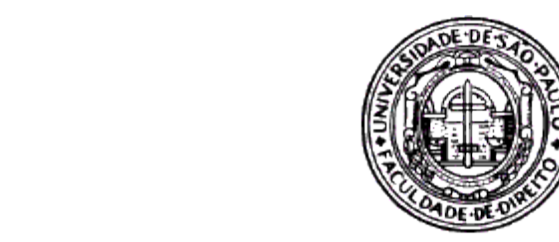

FERNANDO AWENSZTERN PAVLOVSKY

\title{
PODER GERAL DE EFETIVAÇÃO
}

Dissertação de Mestrado

Orientador: Prof. Dr. Cândido Rangel Dinamarco

Faculdade de Direito da Universidade de São Paulo São Paulo 


\title{
PODER GERAL DE EFETIVAÇÃO
}

\author{
Dissertação de Mestrado
}

Orientador: Prof. Dr. Cândido Rangel Dinamarco

Dissertação de Mestrado apresentada à Faculdade de Direito da Universidade de São Paulo como requisito parcial para a obtenção do título de Mestre em Direito.

Área de concentração: Direito Processual.

Subárea: Direito Processual Civil.

Faculdade de Direito da Universidade de São Paulo

São Paulo 
Autor: Fernando Awensztern Pavlovsky

Título: Poder Geral de Efetivação

Orientador: Prof. Dr. Cândido Rangel Dinamarco

Dissertação de Mestrado apresentada à Faculdade de Direito da Universidade de São Paulo como requisito parcial para a obtenção do título de Mestre em Direito.

Área de concentração: Direito Processual.

Subárea: Direito Processual Civil.

Aprovado em

Banca examinadora:

Prof. Dr.

Julgamento:

Instituição:

Assinatura:

Prof. Dr.

Julgamento:

Instituição:

Assinatura:

Prof. Dr.

Julgamento:

Instituição:

Assinatura: 


\section{AGRADECIMENTOS}

Aos meus pais, Arnaldo e Léia, pela vida, pelo amor incondicional e pelo apoio contínuo.

Ao querido Professor Cândido Rangel Dinamarco, um dos maiores expoentes e pensadores do Processo Civil, por quem sempre nutri imensa admiração e em cuja obra, perene como uma acácia, sempre encontrei todas as respostas, pela oportunidade única de ter sido seu orientando.

A todos os meus mentores, responsáveis pela minha sólida formação, e em especial ao meu primeiro mestre de Processo Civil, Milton Paulo de Carvalho Filho, que o tempo transformou em amigo e colega de profissão, responsável por me introduzir em tal ciência e por ela me fazer encantar.

A todos meus amigos, irmãos escolhidos, sem os quais a caminhada pela estrada da vida seria muito mais árdua.

À minha amada esposa, Rebeca, parceira de jornada, pelo companheirismo e cumplicidade, pelo apoio e incentivo para jamais desistir.

Por fim, à minha princesa, Helena, que esteve presente desde o exame de qualificação, ainda no ventre de sua mãe. Obrigado por me fazer compreender o que é importante, ensinando-me o significado e o real sentido da vida. 
"O direito não é mero pensamento, mas sim força viva. Por isso, a Justiça segura numa das mãos a balança, com a qual pesa o direito, e na outra a espada, com a qual o defende.

A espada sem a balança é a força bruta, a balança sem a espada é o direito impotente; completam-se mutuamente; e, na realidade, o verdadeiro estado de direito só pode reinar quando a força despendida pela Justiça para empunhar a espada corresponda à habilidade que emprega em manejar a balança." (Rudolf Von Ihering) 


\section{RESUMO}

O ordenamento jurídico se divide em dois planos distintos: o do direito material e o do direito processual. Segundo a teoria instrumentalista, que enxerga o processo de uma visão teleológica, este é um instrumento voltado à atuação do direito material (escopo jurídico) e, além disso, à consecução de outras finalidades decorrentes de sua natureza de relação jurídica de direito público (escopos sociais e político). O processo existe pela necessidade de dar concretude a um direito cujo plano material não foi suficiente para encerrar-lhe o ciclo de produção. Em outras palavras, não sendo observado o direito material, entram em cena o processo e a atividade jurisdicional por ele provocada para encerrar a crise jurídica proveniente daquela inobservância, garantindo assim a preservação do ordenamento e o bem-estar social. Em razão dessa visão publicista, segundo a qual o processo transcende os interesses meramente privados envolvidos no plano do direito material, vem sendo uma tendência da legislação atribuir maiores poderes ao juiz, representante na relação jurídica processual desse interesse público, para assegurar que o processo alcance seus escopos e seja um instrumento efetivo. O Código de Processo Civil de 2015, seguindo essa tendência, deu forte impulso ao incremento dos poderes do juiz, ao estabelecer em seu artigo 139, IV, uma cláusula geral que conferiu ao magistrado a possibilidade de impor medidas indutivas, coercitivas, mandamentais ou sub-rogatórias não previamente tipificadas em lei para assegurar o cumprimento de suas decisões, inclusive em ações cujo objeto seja o pagamento de quantia certa, consagrando assim o princípio da atipicidade das medidas executivas. Atribuiu-se, assim, ao juiz verdadeiro poder geral de efetivação, que merece ser bem analisado e delimitado para que seu exercício se dê de maneira a garantir a efetividade da tutela jurisdicional e do processo como instrumento de realização da justiça, e não acabe se transformando em arbítrio.

Palavras-chave: Instrumentalidade. Publicização do processo. Poderes do Juiz. Efetividade. Medidas indutivas. Medidas coercitivas. Medidas mandamentais. Medidas sub-rogatórias. Atipicidade das medidas executivas. Poder geral de efetivação. 


\begin{abstract}
The legal system is divided into two distinct plans: substantive law and procedural law. According to the instrumentalist theory, which sees the process under a teleological vision, it is an instrument in regards to the performance of the material law (legal scope) and, in addition to that, to the achievement of other purposes deriving from its nature of legal relationship of public law (social and political scopes). The procedure exists in order to give concrete substance to a right whose material plan was not sufficient to resolve the production cycle. In other words, when the non-observance of the material law, the process and the jurisdictional activity brought by it in order to close the legal crisis arising from that non-observance, thus guaranteeing the preservation of planning and social welfare. Due to this publicist view through which the procedure transcends the purely private interests involved in material law area, it has been a tendency for legislation to give greater power to the judge, representative in the procedural legal relationship of that public interest, to ensure that the procedure reaches their scopes and be an effective instrument. The Brazilian Procedure Civil Code of 2015, following this trend, gave a strong boost to the powers of the judge by establishing in its article 139, IV, a general clause that gave to the judge the possibility of imposing inductive, coercive, mandatory and subrogatory measures not previously established in law to ensure compliance with their decisions, including claims regarding payments of certain amount, enshrining then the principle of atypility of executive measures. Therefore, the judge was granted with a general power of execution, which deserves to be analyzed and delimited so that its exercise is given to ensure the effectiveness of the judicial protection and the procedure as an instrument for the accomplishment of justice, and is not transformed into discretion.
\end{abstract}

Keywords: Instrumentality. Public nature of procedure. Powers of the Judge. Effectiveness. Inductive measures. Coercive measures. Mandatory measures (judge orders). Subrogatory measures. Atypicality of the means of enforcement. General power of enforcement. 


\section{SUMÁRIO}

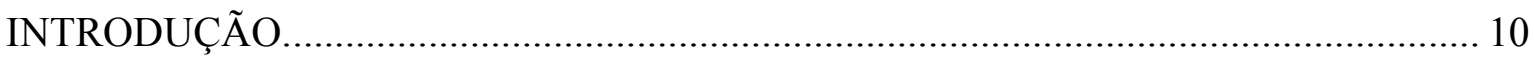

CAPÍTULO I - JURISDIÇÃO E PROCESSO ................................................................ 20

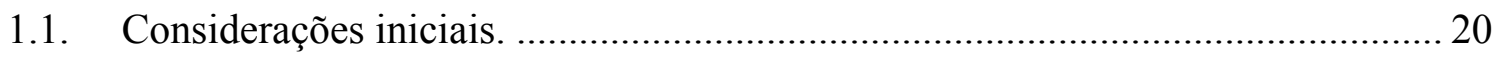

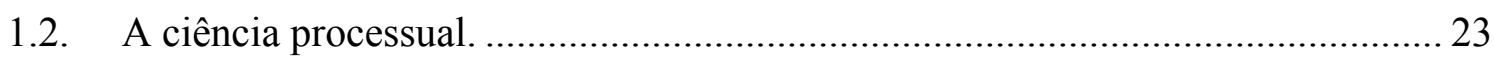

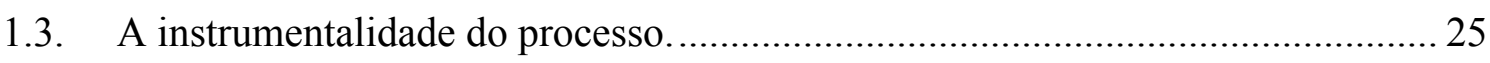

1.4. Instrumentalidade e garantismo: a publicização em oposição a uma concepção

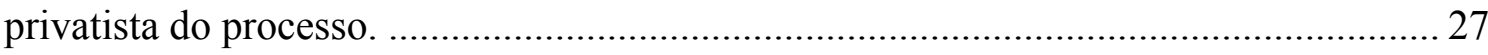

1.5. O juiz e sua responsabilidade pela efetividade do processo.............................. 34

CAPÍTULO II - A RELAÇÃO PROCESSUAL E OS PODERES DO JUIZ..................... 36

2.1. A posição do juiz na relação jurídica processual................................................... 37

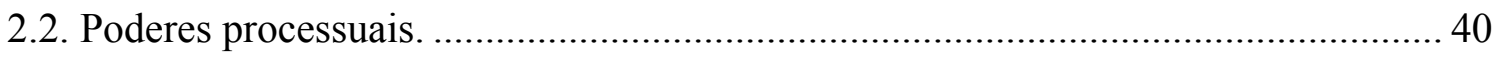

2.3. Os poderes do juiz na condução do processo a uma tutela tempestiva, justa e efetiva.

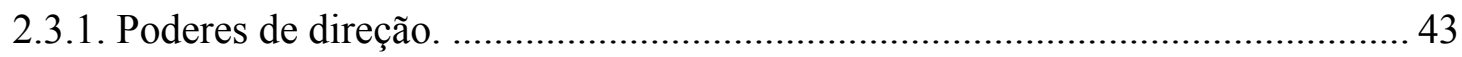

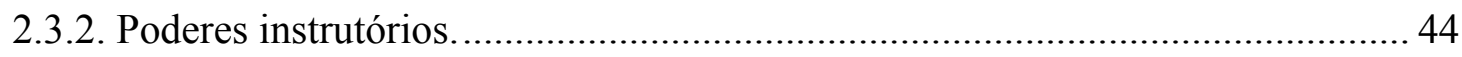

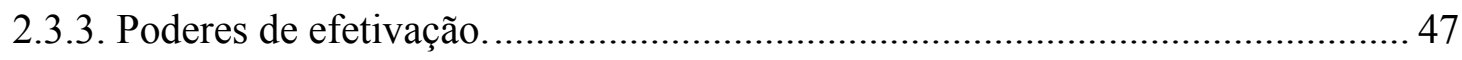

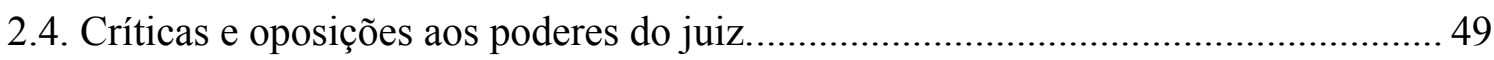

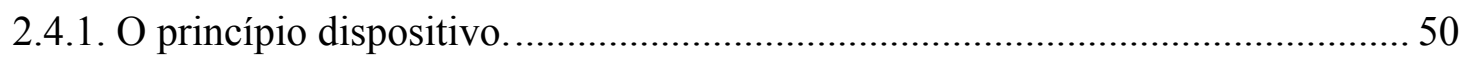

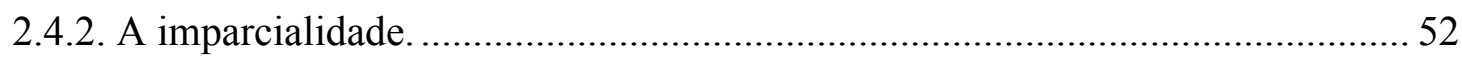

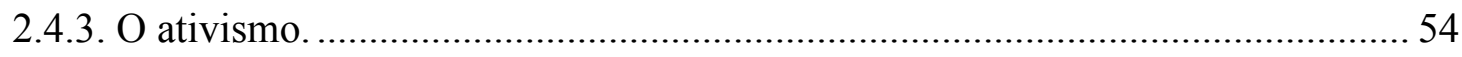

CAPÍTULO III - PODER GERAL DE EFETIVAÇÃO. ................................................. 57

3.1. Poder geral de efetivação e outros poderes gerais (de cautela, de antecipação da tutela jurisdicional e de editar tutelas provisórias): paralelo e distinção. ........................ 57

3.2. A cláusula geral do poder de efetivação no Código de Processo Civil de 2015. ..... 59

3.3. O poder geral de efetivação nas ações para cumprimento de prestações pecuniárias:

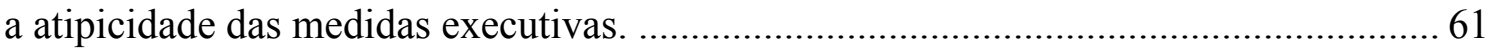

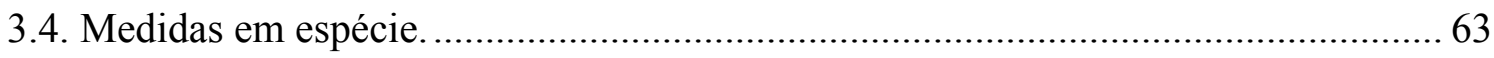




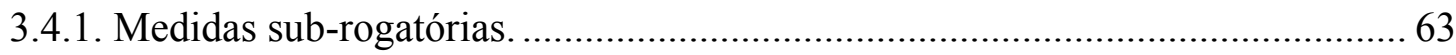

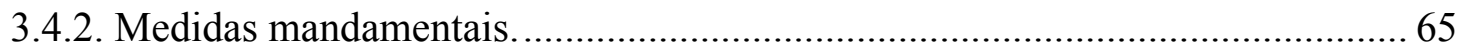

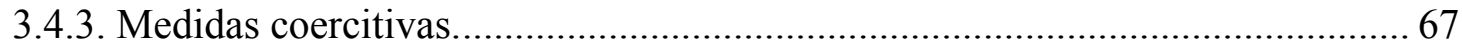

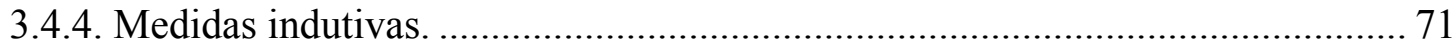

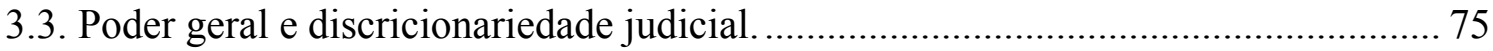

3.4. Parâmetros para o exercício do poder geral de efetivação e imposição das medidas

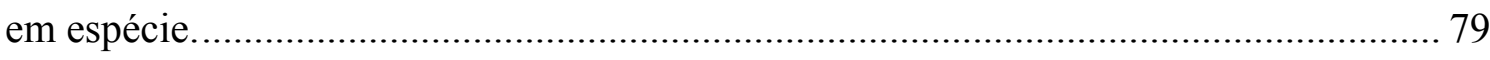

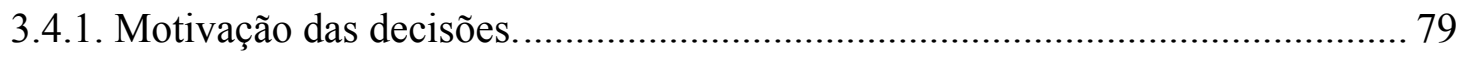

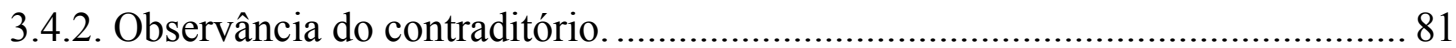

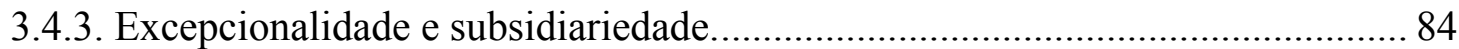

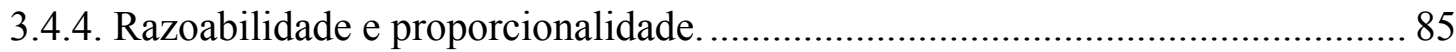

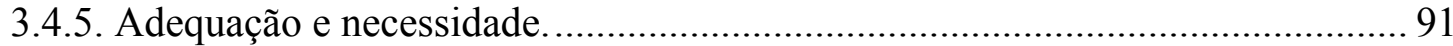

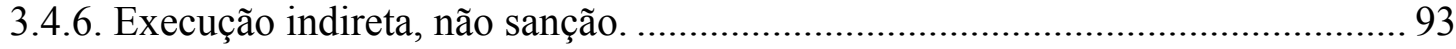

CAPÍTULO IV ,- ANÁLISE DE CASOS E JURISPRUDÊNCIA................................... 95

CONCLUSÃO

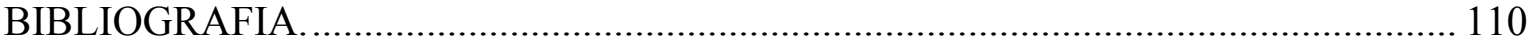




\section{INTRODUÇÃO}

Após longa evolução que lhe conferiu autonomia e independência como ciência, o Direito Processual hoje é concebido, pela visão instrumentalista de seu fenômeno - o processo -, como meio de garantir e dar concretude ao direito material.

O processo não é um fim em si mesmo. É um instrumento pelo qual se materializa a atividade jurisdicional e que tem como seu principal escopo eliminar crises jurídicas provenientes do direito material, estabilizando e pacificando conflitos no seio da sociedade.

Em sua essência, é uma relação jurídica tríplice, que envolve a parte autora, que busca a tutela jurisdicional; a parte ré, em face da qual se objetiva a proteção e o comando estatal; e o Estado-juiz, perante o qual se coloca a pretensão e que detém a função jurisdicional.

Por força da relação jurídica processual,

de um lado o juiz assume o concreto dever de decidir e realizar o direito deduzido em juízo e, de outro, as partes ficam obrigadas, perante ele, a prestar uma colaboração indispensável e a submeter-se aos resultados dessa atividade comum. Eis por que se trata de uma relação jurídica complexa, evolutiva, de direito público ${ }^{1}$.

Diferentemente da relação jurídica de direito material, que se dá entre os sujeitos envolvidos no plano substancial por direitos e obrigações, na relação jurídica processual há um terceiro componente, com o qual esses sujeitos estabelecem direta ligação, e a quem cabe resolver a crise jurídica advinda daquela primeira, o Estadojuiz.

Ao juiz cabe conduzir e impulsionar esse método de solucionar controvérsias $^{2}$, devendo zelar pela observância das garantias que lhe caracterizam (contraditório e ampla defesa) e buscar dar a seus comandos efetividade. Para isso, é indispensável que possua poderes para administrar a justiça de um modo ativo, rápido e seguro $^{3}$ e impor o cumprimento de suas decisões.

Infelizmente, parece não mais se sustentar nos dias atuais a opinião de Sidnei Agostinho BENETI, segundo a qual:

\footnotetext{
${ }^{1}$ Cândido Rangel Dinamarco, Fundamentos do Processo Civil Moderno, p. 262.

2 José Roberto dos Santos Bedaque, Efetividade do Processo e Técnica Processual, p. 80.

${ }^{3}$ Piero Calamandrei, Instituciones de Derecho Procesal Civil, p. 395.
} 
Por bem ou por mal, com maior ou menor dose de recalcitrância, acabam sendo executadas as decisões judiciais, mesmo que largamente alardeada a oposição à execução. Podem ser adiadas, podem ser diluídas as notícias da execução da decisão judicial, de modo a evitar-lhes o impacto, mas, se olharmos bem, com distância histórica, veremos que as decisões judiciais ainda são sempre executadas no Brasil, mostrando a vitalidade do Estado brasileiro, colocada sobre os ombros do Poder Judiciário ${ }^{4}$.

A experiência recente nos mostra que a conhecida expressão “decisão judicial não se discute, se cumpre” não possui a mesma solidez de outrora. São diversos os exemplos de menoscabo e desprestígio a decisões judiciais. Apenas para ilustrar, podemos citar diversos casos recentes de grande repercussão de descumprimento de decisões do Supremo Tribunal Federal, como: descumprimento à decisão do Ministro Marco Aurélio Mello sobre o afastamento do Presidente do Senado Federal ${ }^{5}$ do cargo; descumprimento da decisão do Ministro Luiz Fux para que o projeto das dez medidas contra a corrupção retornasse do Senado à Câmara dos Deputados; descumprimento da decisão do Ministro Luís Roberto Barroso para que o projeto de Lei Geral de Telecomunicações permanecesse no Senado e não fosse encaminhado para sanção presidencial; a tentativa de aprovar projeto de lei e até mesmo emenda constitucional para autorizar a vaquejada, já declarada inconstitucional pela Suprema Corte. Isso para ficar apenas nos exemplos que envolvem a mais alta Corte do país. Se lá está assim, como estará o respeito a decisões judiciais nas instâncias inferiores? ${ }^{6}$

\footnotetext{
${ }^{4}$ Da conduta do juiz, p. 201.

${ }^{5} \mathrm{O}$ próprio Renan Calheiros, Presidente do Senado Federal à época, figura pública formadora de opinião, disse em alto e bom tom na ocasião que: "Nenhuma decisão ilegal é para ser cumprida, mesmo que seja decisão judicial. É um dever de cidadania" (http://www.conjur.com.br/2016-dez-13/decisao-ilegal-naocumprida-renan-liminar). Quem julga a ilegalidade de uma decisão judicial? A própria parte a quem a decisão é prejudicial? Em um Estado Democrático de Direito, há meios legítimos para se questionarem as decisões com as quais não se concorda. Ou há respeito pelas Instituições e pelos Poderes constituídos, ou retorna-se ao estado da selva e à justiça privada.

${ }^{6}$ É certo que os exemplos citados de resistência a ordens emanadas do Supremo Tribunal Federal refletem uma crise institucional que há muito vinha-se esboçando, como já havíamos de certa forma projetado no nosso "Do ativismo à onipotência: o Estado de Coisas Inconstitucional e a hipertrofia do Poder Judiciário". A queda de braço entre Legislativo e Judiciário, mais precisamente entre Congresso Nacional e Supremo Tribunal Federal, atingiu seu ápice no último capítulo recente, em que foram impostas medidas cautelares diversas da prisão ao Senador Aécio Neves. Após o Senado Federal sinalizar com a possibilidade de descumprir as determinações, o Pretório Excelso por maioria acabou por recuar, permitindo que a Casa Legislativa decidisse pela manutenção ou não das medidas impostas e, em última análise, pela submissão ou não à decisão judicial. Submetida a decisão judicial ao referendo do Senado, este a rejeitou. Passando ao largo das discussões quanto ao acerto ou não de tal decisão, o fato é que ainda que a solução tenha sido correta, a sensação que se transmite é de enfraquecimento da autoridade da decisão judicial. Como será visto mais adiante, um dos escopos do processo é precisamente conscientizar os cidadãos e os educar para a defesa de direitos próprios e respeito aos alheios, e a preocupação é justamente a proliferação dessa sensação com o consequente desrespeito sistêmico à autoridade das decisões judiciais.
} 
A efetividade do processo como instrumento para solucionar conflitos é preocupação constante e permanente tanto dos estudiosos desse ramo como dos operadores do direito em geral ${ }^{7}$.

De nada adianta garantir a inafastabilidade da jurisdição e do acesso à justiça (artigo $5^{\circ}, \mathrm{XXXV}$, da Constituição Federal) se o sistema não fornece um meio efetivo para a concreção dessas garantias.

Como bem define Kazuo WatanABe, o conteúdo da garantia do acesso à justiça compreende na realidade o acesso a uma ordem jurídica justa ${ }^{8}$. Para tanto, o sistema processual deve assegurar que a tutela jurisdicional atenda aos aspectos de qualidade, tempestividade e efetividade ${ }^{9}$. Se isso não ocorre, a garantia passa a ser algo meramente formal, que no fim das contas acaba por facilitar apenas o ingresso em juízo, mas não o egresso, ou, em outros termos, a plena atuação e satisfação do direito.

São inúmeras as alterações normativas promovidas pelo legislador na busca de instituir mecanismos de racionalização do processo, a fim de que este cumpra sua função de dar concretude ao direito material, o que só sucede quando a tutela é tempestiva e eficaz, pois, conforme a clássica lição de CHIOvEnDA: "il processo deve dare per quanto è possibile praticamente a chi há un diritto tutto quello e proprio quello ch'egli há diritto di conseguire", justiça atrasada não é justiça; senão injustiça qualificada e manifesta" ${ }^{11}$.

Nessa tentativa, foram introduzidos até mesmo na Constituição Federal, por meio das Emendas Constitucionais n. 19/1998 e n. 45/2004, os princípios da eficiência (também voltado ao Poder Judiciário) e da razoável duração do processo.

Se o processo falhar em seus escopos, falidos estarão o sistema de justiça e a jurisdição como atividade de competência exclusiva do Estado, cabendo aos

\footnotetext{
${ }^{7}$ Como já observava há cerca de duas décadas José Rogério Cruz e Tucci: "relegando a um plano secundário as construções de cunho teórico, que tanta relevância ostentaram até há bem pouco tempo, os processualistas passaram a preocupar-se com um valor fundamental, ínsito à tutela dos direitos, qual seja, a imprescindibilidade da efetividade do processo, enquanto instrumento de realização da justiça" (Tempo $e$ processo, p. 63).

${ }^{8}$ Acesso à justiça e sociedade moderna.

${ }^{9}$ Cândido Rangel Dinamarco, Instituições de Direito Processual Civil, vol. I, p. 117 e ss.

${ }^{10}$ Dell'azione nascente dal contratto preliminare, in. Saggi di Diritto Processuale Civile. 2. ed. Roma: Foro It., 1930, n. 3, p. 110.

${ }^{11}$ Oração aos Moços.
} 
sujeitos buscar outros mecanismos alternativos, como a conciliação e a mediação, ou mesmo a arbitragem ${ }^{12}$, ou retroceder a formas primitivas como a autotutela.

\section{E para que o processo seja um mecanismo efetivo para a} concretização do direito e a pacificação social, e não um instrumento de perpetuação de crises $^{13}$, que serve de estratagema àqueles que, desprovidos de uma ética processual (improbus litigator), visam a descumprir a lei e a postergar o adimplemento de obrigações $^{14}$, é de vital importância que o juiz seja dotado de poderes amplos para assegurar o cumprimento de suas decisões e saiba fazer bom uso deles em benefício de uma tutela jurisdicional tempestiva, justa e efetiva.

No âmbito da legislação processual, no decorrer das últimas décadas, foram introduzidas no sistema diversas inovações com o intuito de aperfeiçoar o processo sob os aspectos da tempestividade e da efetividade, para proporcionar assim ao consumidor dos serviços judiciários um processo civil de resultados ${ }^{15}$. E para atingir tal

\footnotetext{
${ }^{12}$ Embora nenhuma dessas seja dotada de caráter impositivo, como é a jurisdição, exatamente pela falta de poderes de coerção. Carlos Alberto CARMONA, um dos, senão o maior expoente sobre arbitragem no Brasil, sustenta o caráter jurisdicional do instituto. Para ele, não é impositivo que a atividade jurisdicional seja privativa e exclusiva do Estado. Se todo poder emana do povo, e os particulares desejam conferir a um terceiro, o árbitro, por meio da convenção arbitral, a função de solucionar uma crise jurídica, um conflito de interesses, não há razão para considerar essa atividade menos jurisdicional do que a praticada pelo Estado. E de acordo com o autor, a tese da jurisdicionalidade da arbitragem foi encampada pela Lei n. 9.307/96, ao estabelecer que a sentença arbitral não depende de homologação pelo Poder Judiciário. Contudo, o próprio autor reconhece que o que difere a atividade exercida pelo juiz togado daquela desenvolvida pelo árbitro é a capacidade de efetivar sua decisão: "Giuseppe Saredo ensina que seriam cinco os componentes da jurisdição: a notio, que corresponderia à faculdade de conhecer de uma causa; a vocatio, que seria a faculdade de fazer intervir no juízo todos aqueles cuja presença seria útil à justiça e ao conhecimento da verdade; a coertio, direito de fazer-se respeitar, de reprimir as ofensas que lhe forem feitas no exercício de suas funções, o iudicium, direito de julgar e pronunciar sentenças; e a executio, direito de tornar obrigatória e coativa, em nome do poder soberano, a obediência às próprias ordens e decisões (...). Sob tal enfoque, o árbitro seria dotado de notio, vocatio e iducicium, enquanto só as decisões do juiz togado estariam caracterizadas pela coertio e pela executio. Marco Tullio Zanzucchi simplifica as características de jurisdição, que compreenderia apenas três faculdades: a) uma faculdade de decisão (notio), que compreenderia o poder de conhecer, prover, decidir e recolher o material necessário (instruir a causa) para a tutela de um dado interesse; b) uma faculdade de coerção (imperium); e c) uma faculdade de documentação (...). Segundo esta última visão, seria correto afirmar que o árbitro estaria dotado das faculdades de decisão e documentação, enquanto somente ao juiz tocaria a faculdade de coerção" (Arbitragem e Processo, p. 264-265).

${ }^{13}$ A efetividade do processo é também responsável pela própria imagem da Justiça, pois como bem assinala Cândido Rangel Dinamarco: "onde a justiça funciona mal, transgressores não a temem e lesados pouco esperam dela" (Instituições..., vol. I, p. 133), e o bom funcionamento da justiça, claro que entre outros inúmeros fatores, passa necessariamente pela existência de um instrumento efetivo para seu alcance.

${ }_{14}$ Como ironiza Marcelo Abelha Rodrigues, ao comentar a previsão normativa do dever de boa-fé e cooperação, "se o processo fosse um mar de rosas perfumadas certamente o legislador não teria perdido seu tempo em dizer, quase em tom de pátrio poder e com status de norma fundamental, algo que deveria ser óbvio e ululante". Infelizmente, como assinala o autor, "o processo é cheio de atalhos que permitem que, sob a sombra do contraditório, seja possível obstruir o caminho da satisfação do direito" ( $O$ que fazer quando o executado é um 'cafajeste'? Apreensão de passaporte? Da carteira de motorista? Disponível em http://www.migalhas.com.br/dePeso/16,MI245946,51045-O+que+fazer+quando+o+executado+e+um+cafaje ste+Apreensao+de+passaporte. Acesso em 2/9/2017).

${ }^{15}$ Cândido Rangel Dinamarco, $A$ reforma da reforma, p. 36 e ss.
} 
desiderato, as reformas gradativamente incrementaram os poderes do juiz, na busca de tornar mais concreta uma promessa abstrata de tutela efetiva, atacando o mal do tempo do processo e implementando sua potencialidade de criar resultados verdadeiros ${ }^{16}$.

Podem ser citados como exemplos: o poder de antecipação dos efeitos da tutela incluído no artigo 273 do Código de Processo Civil de 1973 na reforma de 1994; o poder de concessão da tutela específica ou de determinação de providências para assegurar resultado prático equivalente em obrigações de fazer ou não fazer, bem como de imposição de medidas, como busca e apreensão, remoção de pessoas e coisas, desfazimento de obras e impedimento de atividade nociva para sua efetivação, que passou a ser previsto no artigo 461 do Código revogado na reforma de 1994; os poderes ampliados na reforma de 2002, com a possibilidade de fixação de multa por tempo de atraso (astreintes) e sua extensão também para as ações para entrega de coisa $\left(\S 5^{\circ}\right.$ do artigo 461 e artigo 461-A do referido código), entre outros ${ }^{17}$.

Mais precisamente com relação a essas últimas alterações, que trouxeram para o âmbito do processo civil comum a técnica da execução específica, prevista para ações envolvendo relação de consumo ${ }^{18}$ já desde 1990 com o advento do Código de Defesa do Consumidor, passou-se a adotar a coercibilidade das obrigações ${ }^{19}$.

Assim, o sistema passou a prever, primeiramente para as ações de obrigação de fazer e não fazer, cuja execução por imposição imperativa do Estado-juiz é mais dificultosa - uma vez que o cumprimento da imposição depende muito da disposição do obrigado, sendo muito difícil obter sem a vontade deste o resultado ao qual

\footnotetext{
${ }^{16}$ Eduardo de Albuquerque Parente, Jurisdição e poder, p. 190 e 193-194.

${ }^{17}$ Eduardo de Albuquerque Parente cita ainda outros dispositivos que encerrariam acréscimo de poder ao juiz em diferentes graus e por motivos diversos (Ob. cit., p. 193).

${ }_{19}^{18}$ Artigo 84 do Código de Defesa do Consumidor.

19 Nas clássicas lições de Enrico Tullio LiEBman, a satisfação coativa do direito do credor, que se faz mediante o exercício do poder dos órgãos jurisdicionais que, superando o óbice criado pelo inadimplemento do devedor, atingem esse objetivo prescindindo da boa vontade e colaboração deste, opera-se apenas por meios sub-rogatórios. A execução deve recair apenas sobre os bens do devedor e não sobre a sua pessoa. Segundo LIEBMAN a obrigação em si mesma seria sempre incoercível, porque o direito não poderia de maneira alguma constranger o devedor a ter, quando não quer, o comportamento a que é obrigado (Manual de Direito Processual Civil, p. 266). Conforme aponta DinAMARCO, a execução específica constitui negação desse tradicional postulado da incoercibilidade das obrigações, decorrente do dogma da intangibilidade da vontade humana. Segundo o mestre das Arcadas, foi com Chiovenda e Calamandrei que se procedeu a uma distinção entre infungibilidade natural e infungibilidade jurídica, estabelecendo-se a ideia de que em nada interfere na dignidade da pessoa, ou em sua liberdade de querer ou não querer, atividades estatais imperativas que produzam situação jurídica final equivalente (tutela específica) ou então a imposição de medidas de pressão psicológica para compelir o obrigado a cumprir com a obrigação (A reforma da reforma, p. 220).
} 
o credor tem direito ${ }^{20}$-, a possibilidade de o juiz, mediante meios coercitivos, vencer a resistência do obrigado, pressionando-o psicologicamente a cumprir a ordem judicial.

Posteriormente, tal possibilidade passou a ser admitida também nas ações para entrega de coisa, afastando a até então regra da conversão da obrigação não cumprida em perdas e danos ${ }^{21}$, que passou a tornar-se medida excepcional, apenas quando realmente impossível a tutela específica. Nas sempre elucidativas lições de DiNAMARCO: “a execução indireta, ou por coerção, deixa de figurar como algo muito excepcional e passa a representar um papel muito importante entre as atividades destinadas à satisfação dos direitos e efetividade da tutela jurisdicional” ${ }^{, 2}$.

E o Código de Processo Civil de 2015, como tendência característica das legislações processuais modernas, ao dilatar os poderes do juiz na direção do processo ${ }^{23}$, trouxe de forma expressa, em capítulo próprio no rol dos poderes do juiz, uma incumbência genérica de determinar "todas as medidas indutivas, coercitivas, mandamentais ou sub-rogatórias necessárias para assegurar o cumprimento de ordem judicial".

Além de consagrar em definitivo a técnica da execução indireta, que passou a ser estendida também para ações cujo objeto seja o pagamento de quantia, que da mesma forma passam a adotar o modelo de atipicidade das medidas executivas ${ }^{24}$, o dispositivo estabelece na realidade uma cláusula geral ${ }^{25}$ que confere verdadeiro poder

\footnotetext{
${ }^{20}$ Cândido Rangel Dinamarco, A reforma da reforma, p. 219.

${ }^{21} \mathrm{O}$ que seria apenas uma meia justiça (Idem, ibidem, p. 221).

22 Ibidem, p. 223-224.

${ }^{23}$ José Rogério Tucci, $A$ ampliação dos poderes do juiz no novo CPC e o princípio da legalidade. Disponível
} em: http://www.conjur.com.br/2016-set-27/paradoxo-corte-ampliacao-poderes-juiz-cpc-principio-legalidade. Acesso em 2/9/2017.

${ }^{24}$ Ao que o processualista Fernando da Fonseca GAJARDONI denominou de "revolução silenciosa da execução por quantia" (Artigo disponível em: http://jota.uol.com.br/a-revolucao-silenciosa-da-execucao-porquantia, acesso em 22/6/2016).

${ }^{25}$ Sobre a definição de cláusula geral e a sua expansão do Direito Processual, valemo-nos das lições de Fredie Didier Jr.: "Cláusula geral é uma espécie de texto normativo, cujo antecedente (hipótese fática) é composto por termos vagos e o consequente (efeito jurídico) é indeterminado. Há, portanto, uma indeterminação legislativa em ambos os extremos da estrutura lógica normativa. (...) A técnica das cláusulas gerais contrapõe-se à técnica casuística. Não há sistema jurídico exclusivamente estruturado em cláusulas gerais (que causariam uma sensação perene de insegurança a todos) ou em regras casuísticas (que tornariam o sistema sobremaneira rígido e fechado, nada adequado à complexidade da vida contemporânea). Uma das principais características dos sistemas jurídicos contemporâneos é exatamente a harmonização de enunciados normativos de ambas as espécies. É indiscutível que a existência de cláusulas gerais reforça o poder criativo da atividade jurisdicional. O órgão julgador é chamado a interferir mais ativamente na construção do ordenamento jurídico, a partir da solução de problemas concretos que lhe são submetidos. (...) as cláusulas gerais têm invadido o Direito processual, que naturalmente sofreu as consequências das transformações da metodologia jurídica no século passado. Afinal, o Direito processual também necessita de normas flexíveis que permitam atender às especiais circunstâncias do caso concreto" (Disponível em: 
geral de efetivação ao juiz, como destaca o Enunciado n. 48 da Escola Nacional de Formação e Aperfeiçoamento de Magistrados (Enfam), com a seguinte redação:

$\mathrm{O}$ art. 139, IV, do CPC/2015 traduz um poder geral de efetivação, permitindo a aplicação de medidas atípicas para garantir o cumprimento de qualquer ordem judicial, inclusive no âmbito do cumprimento de sentença e no processo de execução baseado em títulos extrajudiciais.

Ao fixar uma norma aberta como essa, o legislador "parte da premissa de que, por ser impossível predizer todas as necessidades futuras e concretas, é imprescindível dar poder aos operadores do direito para a identificação e a utilização dos meios processuais adequados às variadas situações"26.

Um dos integrantes da comissão especial de elaboração do Código de Processo Civil na Câmara dos Deputados, Paulo Henrique LuCon, ao comentar o dispositivo e o problema da falta de efetividade das decisões no país, devido ao "péssimo hábito de, no Brasil, não se cumprirem decisões judiciais", afirmou que a comissão chegou à conclusão de que tinha de "conferir poderes aos juízes para essas medidas indutivas. Se o julgador tentou de tudo, buscou bens e não conseguiu, essas medidas podem ser utilizadas como ultima ratio" 27 .

Alguns autores como Luiz Guilherme MARINONI, Sérgio Cruz AREnhart e Daniel Mitidiero identificam em tal previsão a concessão de verdadeiro poder de imperium $^{28}$ ao magistrado, que dá novo significado à atividade jurisdicional, valorizando a autoridade das decisões judiciais e conferindo novos mecanismos de proteção dos direitos ${ }^{29}$.

http://www.frediedidier.com.br/editorial/editorial-81/). V. mais em: http://www.frediedidier.com.br/artigos/ clausulas-gerais-processuais/.

${ }^{\frac{}{26}}$ Luiz Guilherme Marinoni, A legitimidade da atuação do juiz a partir do direito fundamental à tutela jurisdicional efetiva, p. 230.

27 "Devedores podem ter passaporte e carteira de habilitação apreendidos", Valor Econômico, 8/8/2016 (disponível em: http://www.valor.com.br/legislacao/4661725/devedores-podem-ter-passaporte-e-carteira-dehabilitacao-apreendidos, acesso em 10/8/2016).

${ }^{28}$ Sobre o poder de imperium que remonta ao Direito Romano, José Carlos MoREIRA ALVES, em sua clássica obra sobre o tema, ensina que os poderes dos magistrados se resumiam na potestas e no imperium, sendo este último: "a personificação, no magistrado, da supremacia do Estado, supremacia que exige a obediência de todo cidadão ou súdito, mas que está limitada pelos direitos essenciais do cidadão ou pelas garantias individuais concedidas por lex publica. O imperium compreende o poder de levantar tropas e comandá-las, o direito de apresentar propostas aos comícios, a faculdade de deter e punir os cidadãos culpados e a administração da justiça nos assuntos privados" (Direito Romano, p. 18).

${ }^{29}$ O Novo Processo Civil, p. 373. Segundo os autores: "O art. 139, IV, CPC, explícita os poderes de imperium conferidos ao juiz para concretizar suas ordens. A regra se destina tanto a ordens instrumentais (aquelas dadas pelo juiz no curso do processo, para permitir a decisão final, a exemplo das ordens instrutórias no processo de conhecimento, ou das ordens exibitórias na execução) como a ordens finais (consistentes nas técnicas empregadas para a tutela da pretensão material deduzida)" (Novo Código de Processo Civil Comentado, p. 213). 
Além do artigo 139, IV, que estabelece esse poder geral de efetivação, tal prerrogativa foi reproduzida também em outras disposições específicas, como é o caso do artigo 380, que estabelece os deveres de terceiros em colaborar com a causa e no qual consta para eventual descumprimento a possibilidade de imposição das medidas indutivas, coercitivas, mandamentais ou sub-rogatórias, bem como nos artigos 400 e 403, que disciplinam a exibição de documento ou coisa, atribuindo do mesmo modo tais poderes ao magistrado para assegurar a efetivação das decisões em tais casos.

Contudo, ainda que se possa vislumbrar nesses novos poderes um traço característico do imperium romano, pelo qual ao pretor cabia o poder de coerção de tutelar por decretos orais (os interdicta) situações de fato que lhe pareciam justas sem grandes considerações ou maiores motivações ${ }^{30}$, é certo que na atualidade não se pode conceber seja o juiz dotado de um poder irrestrito, quase ilimitado ${ }^{31}$.

Como há muito já destacado por Adolfo Gelsi BIDART, ao comentar sobre os meios de coerção para o cumprimento de sentenças e ordens judiciais no Uruguai na década de 1980, "las medidas para lograr eficacia en el proceso deben ser limitadas para no vulnerar valores superiores $" 32$.

Dessa forma, tornam-se imperiosos um estudo aprofundado e uma análise detida desse novo poder geral para que ele possa ser bem compreendido e utilizado de acordo com os fins aos quais se destina, fixando-se parâmetros para delimitar o seu exercício, a fim de compatibilizá-lo com as garantias dos sujeitos do

\footnotetext{
${ }^{30}$ Como leciona MoreIRA Alves, os interdicta eram decretados pelo pretor apenas baseado no senso de justiça deste sobre situações de fato previstas no Edito, tendo como pressuposto serem verdadeiros os fatos alegados pelo litigante que lhe solicitara a ordem. Ao decretá-los, o pretor apenas inseria a fórmula do interdito sem estabelecer condições para sua concessão (Ob. cit., p. 248). Ao que tudo indica, portanto, esse poder de imperium era absolutamente discricionário, ficando a concessão da ordem ao puro alvedrio do magistrado, o que só veio a mudar, conforme ensina José Rogério CRUZ E TUCCI, com a promulgação em 17 a.C. da lex Julia privatorum, que teve como uma de suas finalidades tolher do arbítrio do pretor o maior número possível de controvérsias, na medida em que "o que anteriormente era regulado pelo pretor, em decorrência de seu imperium e com absoluta discricionariedade, agora vem regulado pela lei, e o pretor não faz mais do que dare iudicium em conformidade com os requisitos previstos na lei" (Jurisdição e poder, p. 27-28).

${ }^{31}$ Ao rechaçar a ideia de discricionariedade judicial quando trata do poder geral de cautela, José Roberto dos Santos BEDAQUE assevera que adotar tal previsão: "não significa, todavia, seja o juiz pátrio dotado de poder discricionário em sede cautelar. Não se equipara ele ao pretor romano, que, no exercício do imperium, podia decretar os interdicta" (Tutela cautelar e tutela antecipada: tutelas sumárias e de urgência, p. 233). Do mesmo modo deve-se compreender com relação ao poder geral de efetivação, de certa forma similar ao poder geral de cautela, conforme será analisado no Capítulo III.

${ }^{32}$ Tendências sobre coerción para el cumplimiento de sentencias y ordenes en los juicios no monetarios Un planteamiento del problema en un país no desarrollado (Uruguai), p. 172.
} 
processo, na medida em que a busca pela efetividade não pode se transformar em autoritarismo ${ }^{33}$.

Há casos recentes de repercussão na sociedade em que o tema de fundo é o poder de efetivar as decisões judiciais, como, por exemplo: medidas coercitivas de suspensão do aplicativo de mensagens WhatsApp, impostas como forma de compelir a empresa a cumprir uma determinação judicial ${ }^{34}$; medidas de suspensão de carteira de motorista, passaporte e cartões de crédito, para forçar o cumprimento de obrigações de pagar.

Até que ponto esse poder geral pode ser exercido? Que tipo de medidas o juiz pode adotar para fazer cumprir suas decisões? O juiz pode determinar o fechamento provisório de uma fábrica para obrigar a empresa a cumprir uma obrigação pecuniária?

Nesse cenário, ganham destaque e relevância o tema do poder geral de efetivação e as medidas que lhe são inerentes.

O objetivo do trabalho será precisamente estudar esse poder geral de efetivação, disposto no Código de Processo Civil de 2015 em seu artigo 139, IV, que atribui ao juiz a incumbência de: "determinar todas as medidas indutivas, coercitivas, mandamentais ou sub-rogatórias necessárias para assegurar o cumprimento de ordem judicial, inclusive nas ações que tenham por objeto prestação pecuniária”.

Buscar-se-á fazer um apanhado geral da evolução do Direito Processual como ciência autônoma até chegar a sua terceira fase metodológica, a instrumentalidade, à qual se dará maior ênfase e atenção.

Será feita uma análise do chamado "garantismo processual", propugnado pela corrente revisionista que se funda em uma concepção privatista do processo, em contraposição ao modelo publicista de visão dos instrumentalistas.

Com base nas premissas fixadas nesse início, será desenvolvida a ideia da efetividade do processo e da necessária participação ativa do juiz para atingir esse objetivo.

\footnotetext{
${ }^{33}$ José Carlos de Araújo Almeida Filho e Mariana Carneiro de Barros, Os poderes do juiz e seus limites Uma análise em matéria probatória e a questão do Juiz Hércules de Ronald Dworkin, p. 142.

${ }^{34}$ Eduardo TALAMINI aborda o caso com muita propriedade em Medidas coercitivas e proporcionalidade: $o$ caso WhatsApp.
} 
No segundo capítulo, pretende-se examinar a relação do juiz com as partes e sua posição na relação processual; abordar as situações jurídicas processuais, com foco na conceituação e definição dos poderes processuais; discorrer sobre os poderes gerais do juiz na condução do processo à luz de uma visão instrumentalista, estabelecendo uma relação entre os poderes de direção, instrutórios e de efetivação com o trinômio tempestividade-qualidade-efetividade ${ }^{35}$; e analisar as objeções e argumentos contrários aos poderes do juiz e sua postura ativa.

Na sequência, o trabalho recairá sobre o seu núcleo principal, objetivando-se definir o poder geral de efetivação. Para tanto, será traçado um paralelo e feita a distinção com os demais poderes gerais (de cautela e de antecipação de tutelas jurisdicionais previstos no revogado Código de Processo Civil de 1973 e de editar tutelas provisórias do Código de Processo Civil de 2015), expondo a cláusula geral desse poder de efetivação disposto no artigo 139, IV, do Código de Processo Civil de 2015 e conceituando as espécies de medidas nele previstas (indutivas, coercitivas, mandamentais e subrogatórias), bem como propondo parâmetros para delimitar o exercício de tal poder e a consequente imposição das medidas possíveis.

Por fim, será feita uma breve análise de casos, de acordo com premissas e ideais fixados no decorrer do trabalho, seguindo-se a sua conclusão.

\footnotetext{
${ }^{35}$ Cândido Rangel Dinamarco, Instituições de Direito Processual Civil, vol. I, p. 117 e ss.
} 


\section{CONCLUSÃO}

Ao longo das últimas décadas, a legislação processual passou por diversas reformas, em sua grande maioria preocupadas em conferir maior efetividade ao processo como instrumento para dar concretude ao direito material, sendo um traço característico delas o incremento dos poderes do juiz.

Com o advento do Código de Processo Civil de 2015, tal tendência ganhou grande dimensão com a previsão contida no artigo 139, IV, que, ao estabelecer uma verdadeira cláusula geral, passou a proporcionar ao magistrado poder para efetivar suas decisões, ampliando sobremaneira o arcabouço de meios disponíveis para assegurar o cumprimento de seus comandos, consagrando em definitivo a atipicidade das medidas executivas, inclusive para ações que tenham por objeto prestação pecuniária.

Assim, passou o juiz a ser dotado de poder geral para adotar quaisquer medidas, não previamente tipificadas em lei, para garantir a efetividade de suas decisões.

No entanto, muito se tem discutido a respeito do limite ao exercício de tal poder, sendo imprescindível fixar critérios e parâmetros para delineá-lo.

Procuramos no presente estudo abordar alguns pontos que tangenciam o tema principal, como a instrumentalidade do processo. Para tanto, foi feita uma breve digressão acerca da evolução da ciência processual até chegar a sua fase instrumentalista, com destaque para a visão publicista do processo e a questão da posição do juiz na relação jurídica processual e a importância de uma postura e atuação ativa do magistrado, a fim de garantir que o processo atinja seus escopos e possa dele extrair os melhores resultados, sendo necessário que a ele sejam conferidos poderes para tanto.

A entrega de uma tutela tempestiva, qualitativa e efetiva depende da outorga (e obviamente do bom uso) ao magistrado de poderes de direção, instrução e efetivação.

No decorrer do trabalho, já foram levantadas premissas, adotadas posições, feitas afirmações e expostas conclusões, que a seguir são sintetizadas:

1. O ordenamento jurídico, conforme a teoria dualista, divide-se em dois planos distintos, o do direito material e o do direito processual. Não sendo o primeiro 
suficiente para encerrar o ciclo de produção do direito, é por meio do segundo que se dá a atuação da vontade concreta do direito substancial.

2. A jurisdição é a atividade heterônoma de resolução de conflitos, pela qual o Estado-juiz, um terceiro independente e imparcial, aplica o direito material a determinada crise jurídica.

3. O processo é o meio, ou instrumento, pelo qual se materializa a jurisdição. É um sistema de realização da atividade jurisdicional.

4. A instrumentalidade é um terceiro marco na evolução do direito processual, que surgiu como forma de corrigir distorções decorrentes das fases que lhe antecederam, as quais, preocupadas em conferir autonomia ao direito processual como ciência, acabaram por cultuar o processo como um fim em si mesmo. Segundo uma concepção publicística do processo, a instrumentalidade resgata a preocupação com os objetivos a que ele visa, passando a encará-lo como meio para atingir determinadas finalidades.

5. Além do escopo jurídico, que é a atuação da vontade concreta do direito, a visão instrumentalista enxerga no processo, de um prisma externo e metajurídico, outros escopos de natureza social, política e cultural. Entre os escopos sociais está a função fundamental do processo, que é a pacificação. Além desse, o processo ainda se destina a educar os cidadãos para a defesa de direitos próprios e o respeito a direitos alheios (educação) e a solidificar e fortalecer as instituições políticas, além de permitir a participação dos cidadãos na vida e nos destinos do Estado (escopo político).

6. A efetividade das decisões é um ponto fundamental para a instrumentalidade, e exerce o juiz, por meio de uma postura ativa, papel essencial para garanti-la.

7. A instrumentalidade não sacrifica as garantias das partes, ao contrário, pois nenhum adepto do instrumentalismo considera possível a efetividade em processo sem respeito ao contraditório e à ampla defesa. Contudo, o garantismo processual, tal como propugnado pela corrente revisionista, que se assenta em uma concepção privatista do processo, em que o juiz é encarado como mero espectador ou árbitro de um jogo, não é compatível com a visão instrumentalista. 
8. Os poderes conferidos ao juiz não significam vantagens ou privilégios, sendo-lhe outorgados para assegurar o cumprimento de deveres igualmente impostos, relacionados ao exercício da jurisdição. Dessa forma, são corolário da natureza pública da relação jurídica processual e do consequente interesse público do Estado-juiz, em que o processo desempenhe corretamente suas funções e atinja seus escopos. Daí porque muitos se referem a eles como poderes-deveres.

9. É por meio do exercício de poderes de direção que o juiz garante uma tutela tempestiva; pelo exercício de poderes instrutórios que o juiz assegura uma tutela qualitativa; e mediante o exercício de poderes executórios ou de efetivação que o juiz entrega uma tutela efetiva.

10. A postura ativa do juiz não afronta o princípio dispositivo, que vem recebendo por parte dos legisladores, e com o apoio da maioria dos doutrinadores, atenuações visando a acentuar o caráter publicístico do processo, nem a imparcialidade, que é respeitada quando o juiz julga sem buscar atender a interesses próprios ou favorecer qualquer das partes e não fere de outra forma o contraditório e a igualdade entre elas.

11. Como característica das últimas reformas legislativas, o Código de Processo Civil de 2015 incrementou os poderes do juiz, conferindo-lhe poder geral para efetivar suas decisões. Por meio de uma cláusula geral prevista no artigo 139, IV, que incumbe ao juiz determinar "todas as medidas indutivas, coercitivas, mandamentais ou sub-rogatórias necessárias para assegurar o cumprimento de ordem judicial”, o atual código consagrou em definitivo a atipicidade das medidas executivas, inclusive para ações cujo objeto seja prestação pecuniária, permitindo ao magistrado escolher e impor medidas não previamente tipificadas em lei.

12. As medidas sub-rogatórias são aquelas pelas quais o Estadojuiz atua em substituição ao obrigado, independentes de sua participação, vontade ou colaboração.

13. Medidas mandamentais são aquelas que trazem em si um comando, uma ordem imperativa, com a exigência de serem cumpridas pelo obrigado, sob pena de desobediência. Diante dessa característica, sua utilização deve restringir-se a hipóteses em que o direito material contenha um comando que exija cumprimento 
específico e não para assegurar o cumprimento de prestações pecuniárias, pois nesse caso estar-se-ia utilizando, ainda que de forma indireta, a prisão por dívidas.

14. Medidas coercitivas são aquelas pelas quais se exerce pressão psicológica no destinatário da ordem judicial, para que ele a cumpra por si mesmo, de forma voluntária, embora não espontânea.

15. Medidas indutivas são aquelas que servem de incentivo ou estímulo para que o obrigado cumpra a determinação judicial.

16. No exercício do poder geral de efetivação, o juiz não exerce poder discricionário. $\mathrm{Na}$ realidade, ainda que a lei permita ao magistrado escolher quaisquer medidas necessárias para assegurar o cumprimento de suas determinações, a opção deve se dar apenas pela medida que se mostrar a melhor providência. Portanto, o juiz jamais fará a escolha segundo critérios de conveniência e oportunidade, pois cabe a ele justificar sua escolha e demonstrar seu acerto pela motivação exposta na decisão.

17. Para a imposição de medidas no exercício do poder geral de efetivação, como regra, o magistrado deve sempre observar o contraditório prévio, dandose dessa forma, à parte contra a qual se voltará a medida, ciência e oportunidade de demonstrar sua desnecessidade ou seu descabimento. Excepcionalmente o contraditório pode vir a ser diferido, aplicando-se analogicamente a previsão contida no artigo $9^{\circ}$, parágrafo único, do Código de Processo Civil.

18. A imposição de medidas atípicas deve-se dar de forma excepcional e subsidiária, apenas depois de esgotados os meios especificamente tipificados e constatada a ineficácia destes.

19. Ao adotar determinadas espécies de medidas, mais precisamente as de natureza coercitiva, o juiz deve observar a proporcionalidade e a razoabilidade, muito embora a tarefa seja difícil, considerando que tais medidas devem essencialmente conter ameaça grave o bastante para servir de pressão psicológica àquele que descumpre a decisão judicial. Além disso, a medida deve-se mostrar adequada e necessária. 
20. Medidas coercitivas ou de execução indireta possuem natureza instrumental, pois visam a atingir determinado resultado. Portanto, não constituem sanção e não devem ser utilizadas como forma de punição.

21. A jurisprudência colhida até o momento sobre a imposição de medidas coercitivas, tais como a suspensão de carteira nacional de habilitação, de passaporte e de cartões de crédito, é oscilante. Embora haja certa inclinação por rejeitar esses tipos de medidas, à exceção de alguns posicionamentos frontalmente contrários a elas, por considerá-las afrontosas a garantias constitucionais e à dignidade da pessoa humana, como não poderia deixar de ser, a aceitação e a aplicação delas têm sido casuísticas, de acordo com as circunstâncias do caso concreto e com a observância dos diversos parâmetros propostos no presente trabalho. 


\section{BIBLIOGRAFIA.}

ABDO, Helena Najjar. O abuso do processo. São Paulo: Saraiva, 2009.

AFONSO DA SILVA, Virgílio. O proporcional e o razoável. Revista dos Tribunais n. 798, São Paulo, 2002, pp. 23-50.

ALMEIDA, Roberto Sampaio Contreras de. Os poderes instrutórios do juiz no processo civil e a instrumentalidade do processo. Revista de Informação Legislativa. Brasília. v.38. n.152. p.89-101. out./dez. 2001.

ALMEIDA FILHO, José Carlos de Araújo e BARROS, Mariana Carneiro de. Os poderes do juiz e seus limites - Uma análise em matéria probatória e a questão do Juiz Hércules de Ronald Dworkin. In. MEDINA, José Miguel Garcia et. al. (Coord.). Os Poderes do Juiz e o Controle das Decisões Judiciais: Estudos em homenagem à Professora Teresa Arruda Alvim Wambier. São Paulo: Revista dos Tribunais, 2008.

AMENDOEIRA JUNIOR, Sidney. Poderes do juiz e tutela jurisdicional: a utilização racional dos poderes do juiz como forma de obtenção da tutela jurisdicional efetiva, justa e tempestiva. São Paulo: Atlas, 2006. Coleção Atlas de Processo Civil.

ARENHART, Sérgio Cruz. A doutrina brasileira da multa coercitiva - Três questões ainda polêmicas. In. MEDINA, José Miguel Garcia et. al. (Coord.). Os Poderes do Juiz e o Controle das Decisões Judiciais: Estudos em homenagem à Professora Teresa Arruda Alvim Wambier. São Paulo: Revista dos Tribunais, 2008.

. Perfis da tutela inibitória coletiva. São Paulo: Revista dos Tribunais, 2003.

; MARINONI, Luiz Guilherme; MITIDIERO, Daniel. O Novo Processo Civil. São Paulo: Revista dos Tribunais, 2015.

; MARINONI, Luiz Guilherme; MITIDIERO, Daniel. Novo Código de Processo Civil Comentado. São Paulo: Revista dos Tribunais, 2015.

AROCA, Juan Montero. El proceso civil llamado 'social' como instrumento de 'justicia' autoritária. In. (coord.). "Processo Civil e Ideologia: Un prefacio, una sentencia, dos cartas y quince ensayos". Valencia, Tirant Lo Blanch, 2006.

. La nueva ley de enjuiciamiento civil española: los poderes del juez y la oralidad.

Revista de Derecho Procesal. Madrid. n.1-3. p.555-635. 2001. 
ASSAD, Sandra Mara Flügel e FERREIRA, Gilberto. Os poderes do juiz no processo civil moderno. RePro, São Paulo, n. 86, 1997.

ASSIS, Araken de. Manual de Execução. 18ª ed. São Paulo: Revista dos Tribunais, 2016.

ÁVILA, Humberto. Teoria dos Princípios, 8ª ed. São Paulo: Malheiros, 2008.

AZEVEDO, André Gomma de. Teoria do conflito e os mecanismos autocompositivos. Técnicas de negociação e mediação. Procedimentos, posturas, condutas e mecanismos aptos a obter a solução conciliada dos conflitos. In. GONÇALVES JR., Jerson Carneiro et. al. (Coord.). Concurso da Magistratura: Noções gerais de direito e formação humanística. São Paulo, Saraiva, 2011.

BALEOTTI, Francisco Emilio. Extensão dos poderes do juiz na execução. Revista de Processo. São Paulo. v.36. n.199. p.123-36. set. 2011.

BANDEIRA DE MELlO, Celso Antônio. Curso de Direito Administrativo. 29a ed. São Paulo: Malheiros, 2012.

BARBOSA MOREIRA, José Carlos. Notas sobre o problema da efetividade do processo. In: Temas de direito processual: terceira série. São Paulo: Saraiva, 1984. p. 27-42.

O processo, as partes e a sociedade. In: Temas de direito processual: oitava série. São Paulo: Saraiva, 2004. p. 29 e ss.

Reformas processuais e poderes do juiz. In: Temas de direito processual: oitava série. São Paulo: Saraiva, 2004. p. 53-68.

. A efetividade do processo de conhecimento. RePro, São Paulo, n. 74, 1994.

. A sentença mandamental: da Alemanha ao Brasil. RePro, São Paulo, n. 97, 2000.

BAPTISTA DA SILVA, Ovídio. Os recursos - viés autoritário da jurisdição, in. Processo e ideologia - o paradigma racionalista. Rio de Janeiro: Forense, 2004, pp. 239-263.

BARROS, Mariana Carneiro de; e ALMEIDA FILHO, José Carlos de Araújo. Os poderes do juiz e seus limites - Uma análise em matéria probatória e a questão do Juiz Hércules de Ronald Dworkin. In. MEDINA, José Miguel Garcia et. al. (Coord.). Os Poderes do Juiz e o Controle das Decisões Judiciais: Estudos em homenagem à Professora Teresa Arruda Alvim Wambier. São Paulo: Revista dos Tribunais, 2008. 
BARROSO, Luís Roberto. Os princípios da razoabilidade e da proporcionalidade no direito constitucional. Revista dos Tribunais - Cadernos de Direito Constitucional e Ciência Política, 23 (1998), pp. 65-78.

. Constituição, Democracia e Supremacia Judicial: Direito e Política no Brasil Contemporâneo. Disponível em: http://www.oab.org.br/editora/revista/revista_11/artigos/constituicaodemocraciaesupremaciajudicial.pdf. Acesso em 20.11.2017.

BEDAQUE, José Roberto dos Santos. Poderes instrutórios do juiz, $7^{\mathrm{a}}$ ed.. São Paulo: Revista dos Tribunais, 2013.

. Tutela cautelar e tutela antecipada: tutelas sumárias e de urgência, $5^{\mathrm{a}}$ ed. São Paulo: Malheiros, 2009.

. Direito e processo - influência do direito material sobre o processo. $5^{\mathrm{a}}$ ed. São Paulo: Malheiros, 2009.

. Efetividade do processo e técnica processual. $3^{\mathrm{a}}$ ed. São Paulo: Malheiros, 2010. . Discricionariedade Judicial. Revista Forense n. 354. Rio de Janeiro: Forense, 2001.

Instrumentalismo e garantismo: Visões opostas do fenômeno processual? In. et al. (Coord.). Garantismo Processual. Brasília: Gazeta Jurídica, 2016.

BENETI, Sidnei Agostinho. Da conduta do juiz. 2a ed. São Paulo: Saraiva, 2000.

BIDART, Adolfo Gleisi. Tendências sobre coerción para el cumplimiento de sentencias y ordenes en los juicios no monetarios - Un planteamiento del problema en un país no desarrollado (Uruguai), .COMPLETAR

BONAVIDES, Paulo. Curso de Direito Constitucional. 31 a ed. São Paulo: Malheiros, 2016.

e YARSHELL, Flávio Luiz. Tutela mandamental nas obrigações de pagamento de quantia. In. ARMELIN, Donaldo (coord.). Tutelas de urgência e cautelares. São Paulo: Saraiva, 2010, pp. 564-571.

BOTELHO, Guilherme. Os poderes processuais do juiz em perspectiva comparada. Revista de Processo. São Paulo. v.40. n.243. p.483-504. maio. 2015. 
BUENO, Cássio Scarpinella. Manual de Direito Processual Civil. São Paulo: Saraiva, 2015 .

. Curso sistematizado de Direito Processual Civil: tutela jurisdicional executiva. v. 3. São Paulo: Saraiva, 2008.

BÜLOW, Oskar Von. La Teoría de las Excepciones Procesales y los Presupuestos Procesales. Trad. de Miguel Angel Rosas Lichtschein. Buenos Aires: Ediciones Jurídicas, 1964.

CALAMANDREI, Piero. Instituciones de derecho procesal civil, según el nuevo código. Trad. Santiago Sentís Melendo. Buenos Aires: Librería El Foro, 1996, v. 1.

- O Magistrado, protagonista do processo jurisdicional? In. MEDINA, José Miguel Garcia et. al. (Coord.). Os Poderes do Juiz e o Controle das Decisões Judiciais: Estudos em homenagem à Professora Teresa Arruda Alvim Wambier. São Paulo: Revista dos Tribunais, 2008.

CANOTILHO, José Joaquim Gomes. Direito Constitucional e Teoria da Constituição. $7^{\mathrm{a}}$ ed. Coimbra: Almedina, 2000.

CAPPELLETTI, Mauro. Juizes legisladores?, trad. Carlos Alberto Álvaro de Oliveira. Porto Alegre: Sérgio Antonio Fabris Editor, 1999.

; GARTH, Bryant. Acesso à justiça. Trad. Ellen Gracie Northfleet. Porto Alegre: Sérgio Antonio Fabris Editor, 1998.

CARMONA, Carlos Alberto. Arbitragem e Processo: Um Comentário à Lei no 9.307/96. $2^{\mathrm{a}}$ ed. São Paulo: Editora Atlas, 2004.

CARNELUTTI, Francesco. Derecho y proceso. Trad. Santiago Sentis Melendo. Buenos Aires: EJEA, 1971.

CARVALHO, Paulo de Barros. Curso de Direito Tributário, $15^{\mathrm{a}}$ ed. São Paulo: Saraiva, 2003.

CHIOVENDA, Giuseppe. Instituições de Direito Processual Civil. 2. ed. Trad. Paolo Capitanio. Campinas: Bookseller, 1998. . Saggi di diritto processuale civile. 2. ed. Roma: Foro Italiano, 1930.

CINTRA, Antonio Carlos de Araújo; GRINOVER, Ada Pellegrini; DINAMARCO, Cândido Rangel. Teoria geral do processo, $23^{\mathrm{a}}$ ed. São Paulo: Malheiros, 2007. 
CIPRIANI, Franco. El proceso civil italiano entre revisionistas y negacionistas. In. AROCA, Juan Montero (coord.). "Processo Civil e Ideologia: Un prefacio, una sentencia, dos cartas y quince ensayos". Valencia, Tirant Lo Blanch, 2006.

DANTAS, Francisco Wildo Lacerda. Os poderes do juiz no processo civil e a reforma do Judiciário. Revista dos Tribunais. São Paulo. v.83. n.700. p.35-9. fev. 1994.

DELGADO, José Augusto. Poderes, deveres e responsabilidade do Juiz. Revista de Processo. São Paulo. v.11. n.42. p.37-57. abr.jun. 1986.

Reflexões contemporâneas (julho/2007) sobre os poderes e deveres do juiz na imposição dos princípios da razoável duração do processo e da moralidade, na relação jurídica formal. In. MEDINA, José Miguel Garcia et. al. (Coord.). Os Poderes do Juiz e o Controle das Decisões Judiciais: Estudos em homenagem à Professora Teresa Arruda Alvim Wambier. São Paulo: Revista dos Tribunais, 2008.

DI PIETRO, Maria Sylvia Zanella. Direito Administrativo. 27ª ed. São Paulo: Atlas, 2014. DIDIER JR., Fredie. Multa coercitiva, boa-fé processual e supressio: aplicação do duty to mitigate the loss no processo civil, in. Revista de processo n. 171. São Paulo, 2009.

. Editorial 81. Disponível em: http://www.frediedidier.com.br/editorial/editorial-81/.

Acesso em: 12.07.2016.

Cláusulas gerais processuais. Disponível em: http://www.frediedidier.com.br/ artigos/clausulas-gerais-processuais/. Acesso em: 12.07.2016.

DINAMARCO, Cândido Rangel. Fundamentos do processo civil moderno. 5. ed. São Paulo: Malheiros, 2002. v. 1.

. Instituições de direito processual civil. 6. ed. São Paulo: Malheiros, 2009. v. 1, 2 e

3. . Instituições de direito processual civil. 3. ed. São Paulo: Malheiros, 2009. v. 4. . A instrumentalidade do processo. $15^{\mathrm{a}}$ ed. rev. e atual. São Paulo: Malheiros, 2013. . Nova era do processo civil, 4. ed. São Paulo: Malheiros, 2013. . A Reforma da Reforma, $6^{\text {a }}$ ed., São Paulo: Malheiros, 2003.

; CINTRA, Antonio Carlos de Araújo; GRINOVER, Ada Pellegrini. Teoria geral do processo, 23ª ed. São Paulo: Malheiros, 2007. 
DONIZETE, Elpídio. Curso didático de processo civil. $20^{\text {a }}$ ed. São Paulo: Atlas, 2017.

FAZZALARI, Elio. Instituições de Direito Processual. Trad. Elaine Nassif. $1^{\mathrm{a}}$ ed. Campinas: Bookseller, 2006.

FELICIANO, Guilherme Guimarães. O modelo de Stuttgart e os poderes assistenciais do juiz: origens históricas do processo social e as intervenções intuitivas no processo do trabalho. LTr: Revista Legislação do Trabalho. São Paulo. v.78. n.5. p.530-41. maio. 2014. FERRAJOLI, Luigi. Direito e Razão: teoria do garantismo penal. $3^{\mathrm{a}}$ ed. São Paulo: Revista dos Tribunais, 2010.

FERRAZ, Leslie. A demora do Judiciário e o custo Brasil. Disponível em http://www.direitodoestado.com/revista/RERE-18-JUNHO-2009-LESLIE-FERRAZ.pdf, acesso em $16 / 11 / 2017$.

FERREIRA, Gilberto; ASSAD, Sandra Mara F. Os poderes do Juiz no processo civil moderno. Revista de Processo. São Paulo. v.22. n.86. p.285-94. abr./jun. 1997.

FERREIRA FILHO, Manoel Gonçalves. Aspectos do Direito Constitucional Contemporâneo. $2^{a}$ ed. São Paulo: Saraiva, 2009.

FILHO, Marçal Justen. Curso de Direito Administrativo. 9a ed. São Paulo: Revista dos Tribunais, 2013.

GAJARDONI, Fernando da Fonseca. A revolução silenciosa da execução por quantia. Disponível em: http://jota.uol.com.br/a-revolucao-silenciosa-da-execucao-por-quantia.

; CAPPELlETTI, Mauro. Acesso à justiça. Trad. Ellen Gracie Northfleet. Porto Alegre: Sérgio Antonio Fabris Editor, 1998.

GODINHO, Robson Renault. Reflexões sobre os poderes instrutórios do juiz: o processo não cabe no "Leito de Procusto". Revista de Processo. São Paulo. v.39. n.235. p.85-117. set. 2014.

GÓES, Gisele Santos Fernandes. Existe discricionariedade judicial? Discricionariedade $x$ termos jurídicos indeterminados e cláusulas gerais. In. MEDINA, José Miguel Garcia et. al. (Coord.). Os Poderes do Juiz e o Controle das Decisões Judiciais: Estudos em homenagem à Professora Teresa Arruda Alvim Wambier. São Paulo: Revista dos Tribunais, 2008. 
GOMES, Sérgio Alves. Os Poderes do Juiz na Direção e Instrução do Processo Civil. Rio de Janeiro: Forense, 1995.

GRAU, Eros Roberto. O direito posto e o direito pressuposto. São Paulo: Malheiros, 1996. GRINOVER, Ada Pellegrini. A iniciativa instrutória do juiz no processo penal acusatório. Revista Forense 347/3-10.

. Abuso do processo e resistência às ordens judiciárias: o contempt of court. In. . A marcha do processo. Rio de Janeiro: Forense Universitária, 2000.

; CINTRA, Antonio Carlos de Araújo; DINAMARCO, Cândido Rangel. Teoria geral do processo, $23^{\mathrm{a}}$ ed. São Paulo: Malheiros, 2007.

GUERRA FILHO, Willis Santiago. Notas para destacar a importância do princípio constitucional da proporcionalidade no delineamento dos poderes do juiz. In. MEDINA, José Miguel Garcia et. al. (Coord.). Os Poderes do Juiz e o Controle das Decisões Judiciais: Estudos em homenagem à Professora Teresa Arruda Alvim Wambier. São Paulo: Revista dos Tribunais, 2008, pp. 115-124.

JUNOY, Joan Picó I. "El derecho procesal entre el garantismo y la eficacia: un debate mal planteado”. Revista de Ciencias Jurídicas de la Universidad Rafael Urdaneta, vol. VI, $n^{\circ} 1,2012$.

KMIEC, Kennan D. The Origin and Current Meanings of Judicial Activism. Disponível em: http://scholarship.law.berkeley.edu/californialawreview/vol92/iss5/4. Acesso em 20.11.2017.

KOZICKI, Katya. O sentido de discricionariedade judicial visto a partir de Hart e o necessário diálogo com Dworkin. Revista da Associação dos Juízes do Rio Grande do Sul, Ano 39, n. 126 (jun. 2012).

LAZZARINI, Álvaro. Magistratura: deontologia, função e poderes do juiz. Revista de Jurisprudência do Tribunal de Justiça do Estado de São Paulo. v.21. n.109. p.13-22. nov./dez. 1987.

LEMOS, Jonathan Iovane de. Das medidas sub-rogatórias e das técnicas executivas prédeterminadas à atipicidade dos meios. Revista de Processo. São Paulo. v.36. n.200. p.12557. out. 2011. 
LIEBMAN, Enrico Tullio. Fondamento del principio dispositivo. In: Problemi Del processo civile. Milano: Morano, 1962. p. 3-17.

- Manual de direito processual civil. Tradução e notas de Cândido Rangel Dinamarco. 3. ed. São Paulo: Método, 2005. v. 1.

LOPES, Maria Elizabeth de Castro. Anotações sobre a discricionariedade judicial. In. MEDINA, José Miguel Garcia et. al. (Coord.). Os Poderes do Juiz e o Controle das Decisões Judiciais: Estudos em homenagem à Professora Teresa Arruda Alvim Wambier. São Paulo: Revista dos Tribunais, 2008. . O Juiz e o Princípio Dispositivo. São Paulo: Revista dos Tribunais, 2006.

MARCATO, Antonio Carlos. Procedimentos Especiais, 9a ed. São Paulo: Malheiros Editores, 2001.

- A legitimidade da atuação do juiz a partir do direito fundamental à tutela jurisdicional efetiva. In. MEDINA, José Miguel Garcia et. al. (Coord.). Os Poderes do Juiz e o Controle das Decisões Judiciais: Estudos em homenagem à Professora Teresa Arruda Alvim Wambier. São Paulo: Revista dos Tribunais, 2008.

; ARENHART, Sérgio Cruz; Luiz Guilherme; MITIDIERO, Daniel. O Novo Processo Civil. São Paulo: Revista dos Tribunais, 2015.

; ARENHART, Sérgio Cruz; Luiz Guilherme; MITIDIERO, Daniel. Novo Código de Processo Civil Comentado. São Paulo: Revista dos Tribunais, 2015.

MARQUES, Silvia Figueiredo. Considerações a respeito da existência ou não da chamada discricionariedade judicial. BDA: Boletim de Direito Administrativo. São Paulo. v.11. n.9. p.533-41. set. 1995.

MAXIMILIANO, Carlos. Hermenêutica e aplicação do direito. $20^{\mathrm{a}}$ ed. São Paulo: Forense, 2011.

MAZZILLI, Hugo Nigro. A defesa dos interesses difusos em juizo. 24 ed. São Paulo: Saraiva, 2011.

MEDINA, José Miguel Garcia. Variações recentes dos poderes executivos do juiz, cumprimento e execução da sentença condenatória. In. et. al. (Coord.). Os Poderes do Juiz e o Controle das Decisões Judiciais: Estudos em homenagem à Professora Teresa Arruda Alvim Wambier. São Paulo: Revista dos Tribunais, 2008, pp. 332-342. 
. Execução Civil. $2^{\mathrm{a}}$ ed. São Paulo: Revista dos Tribunais, 2004.

MEIRELES, Edilton. Medidas sub-rogatórias, coercitivas, mandamentais e indutivas no Código de Processo Civil de 2015. Revista de Processo vol. 247, ano 40. São Paulo: Revista dos Tribunais, setembro/2015.

MENDES, Gilmar Ferreira; BRANCO, Paulo Gustavo Gonet. Curso de Direito Constitucional. $7^{\text {a }}$ ed. São Paulo: Saraiva, 2012.

MIRANDA, Vicente. Poderes do juiz no processo civil brasileiro. São Paulo: Saraiva, 1993.

MITIDIERO, Daniel; MARINONI, Luiz Guilherme; ARENHART, Sérgio Cruz. O Novo Processo Civil. São Paulo: Revista dos Tribunais, 2015.

; MARINONI, Luiz Guilherme; ARENHART, Sérgio Cruz. Novo Código de Processo Civil Comentado. São Paulo: Revista dos Tribunais, 2015.

MONTELEONE, Girolamo. Principios e ideologías del processo civil. Impressiones de um “revisionista”. In. AROCA, Juan Montero (coord.). "Processo Civil e Ideologia: Un prefacio, una sentencia, dos cartas y quince ensayos”. Valencia, Tirant Lo Blanch, 2006.

. El actual debate sobre las orientaciones publicísticas del proceso civil. In. AROCA, Juan Montero (coord.). "Processo Civil e Ideologia: Un prefacio, una sentencia, dos cartas y quince ensayos". Valencia, Tirant Lo Blanch, 2006.

MOREIRA ALVES, José Carlos. Direito Romano. $17^{\mathrm{a}}$ ed. Rio de Janeiro: Editora Forense, 2016.

NAGAO, Paulo Issamu. O Papel do Juiz na Efetividade do Processo Civil Contemporâneo. São Paulo: Malheiros, 2016.

NALINI, José Renato. Ousadia da planície: pautar o CNJ. In LEWANDOWSKI, Ricardo; NALINI, José Renato (orgs.). O Conselho Nacional de Justiça e sua atuação como órgão do Poder Judiciário. Homenagem aos 10 anos do CNJ. São Paulo: Quartier Latin, 2015.

NEGRÃO COSTA, Roberta Pereira. Proporcionalidade: uma clarificação do conceito. Revista Virtual da AGU, Ano IX, n. 95, dez. 2009. Disponível em: http://www.agu.gov.br/noticia/n-95-dez-2009. Acesso em: 5/7/16. 
NEVES, Daniel Amorim Assumpção. Medidas executivas coercitivas atípicas na execução de obrigação de pagar quantia certa - art. 139, IV, do Novo CPC. Revista de Processo: RePro, São Paulo, v. 42, n. 264, p. 107-150, mar. 2017. . Manual de Direito Processual Civil. $3^{\text {a }}$ ed. São Paulo: Método, 2011.

NEVES, Marcelo. A constitucionalização simbólica. $3^{\mathrm{a}}$ ed. São Paulo: Martins Fontes, 2011.

OLIVEIRA, Carlos Alberto Alvaro de. Poderes do juiz e visão cooperativa do processo. Revista da AJURIS. Porto Alegre. v.30. n.90. p.55-84. jun. 2003.

OLIVEIRA NETO, Olavo de. Novas perspectivas da execução civil - cumprimento de sentença. In. SHIMURA, Sérgio e Neves, Daniel Amorim Assumpção (coords.). Execução no processo civil: novidades \& tendências São Paulo: Método, 2005.

PARENTE, Eduardo de Albuquerque. Jurisdição e poder. In. MEDINA, José Miguel Garcia et. al. (Coord.). Os Poderes do Juiz e o Controle das Decisões Judiciais: Estudos em homenagem à Professora Teresa Arruda Alvim Wambier. São Paulo: Revista dos Tribunais, 2008.

PAVLOVSKY, Fernando Awensztern. Do ativismo à onipotência: o Estado de Coisas Inconstitucional e a hipertrofia do Poder Judiciário. In. CONTI, José Mauricio (Coord.). Poder Judiciário: orçamento, gestão e políticas públicas. Vol. II. São Paulo: Almedina, 2018 (No prelo).

- O funcionamento do Judiciário no Reino Unido. Disponível em: https://jus.com.br/artigos/51162/o-funcionamento-do-judiciario-no-reino-unido. Acesso em 20/11/2017.

PORTANOVA, Rui. Princípios do processo civil. Porto Alegre: Livraria do Advogado, 1995.

PUOLI, José Carlos Baptista. Os poderes do juiz e as reformas do processo civil. São Paulo: Juarez de Oliveira, 2002.

RAMOS, Elival da Silva. Ativismo judicial: parâmetros dogmáticos. 1ªed. São Paulo: Saraiva, 2010. 
REDONDO, Bruno Garcia. Os deveres-poderes do juiz no Projeto de novo Código de Processo Civil. Revista de Informação Legislativa. Brasília. v.48. n.190 t.1. p.89-102. abr./jun. 2011.

RIGHI, Ivan Ordine. Os poderes do juiz. Jurisprudência Brasileira: cível e comercio. Curitiba. n.169. p.41-50. 1993.

. Os poderes do juiz. Revista Forense. Rio de Janeiro. v.105. n.406. p.203-15. nov./dez. 2009.

RODRIGUES, Marcelo Abelha. O que fazer quando o executado é um "cafajeste”? Apreensão de passaporte? Da carteira de motorista? Disponível em: http://www.migalhas.com.br/dePeso/16,MI245946,51045-O+que+fazer+quando+o+execut ado+e+um+cafajeste+Apreensao+de+passaporte. Acesso em 2/9/2017.

SANCHES, Sidney. Poder cautelar geral do juiz no processo civil brasileiro. São Paulo: Revista dos Tribunais, 1978.

SARTORI, André Krausburg. Possibilidade (ou não) de redução do montante das astreintes após a sua consolidação, segundo a jurisprudência do Superior Tribunal de Justiça. Disponível em: http://www.abdpc.org.br/abdpc/artigos/Andr\%C3\%A9\%20Krausburg\%20Sartori\%20_VERS\%C3\%8 30\%20FINAL_.pdf. Acesso em 20/11/2017.

STRECK, Lenio. Verdade e Consenso: Constituição, hermenêtica e teorias discursivas. $4^{\mathrm{a}}$ ed., São Paulo: Saraiva, 2011.

e NUNES, Dierle. Como interpretar o artigo 139, IV, do CPC? Carta branca para o arbitrio? Disponível em: https://www.conjur.com.br/2016-ago-25/senso-incomuminterpretar-art-139-iv-cpc-carta-branca-arbitrio. Acesso em: 20/11/2017.

TALAMINI, Eduardo. Medidas coercitivas e proporcionalidade: o caso Whatsapp. In. Cabral, Antonio do Passo, PACELLI, Eugênio e SCHIETTI CRUZ, Rogério (Coord.). Repercussões do Novo CPC, v. 13. Salvador: Juspodivm, 2016.

. Prisão civil e penal e execução indireta. In: WAMBIER, Teresa Arruda Alvim; SHIMURA, Sérgio (Coord.). Processo de execução e assuntos afins. São Paulo: Revista dos Tribunais, 1998.

TARUFFO, Michele. Il processo civile adversary nell'esperienza americana. Pádova: Cedam, 1979. 
.Cultura y Proceso. In. Páginas sobre justicia civil. Madrid: Marcial Pons, 2009. . Poderes probatorios de las partes y del juez en Europa. Doxa: Cuadernos de Filosofía del Derecho. Alicante. n.29. p.249-71. 2006.

THEODORO JÚNIOR, Humberto. Curso de Direito Processual Civil, v. I, 41 a ed. Rio de Janeiro: Editora Forense, 2004.

TUCCI, José Rogério Cruz e. Tempo e processo. São Paulo: Revista dos Tribunais, 1997. - Ampliação dos poderes do juiz no novo CPC e princípio da legalidade. Disponível em: http://www.conjur.com.br/2016-set-27/paradoxo-corte-ampliacao-poderes-juizcpc-principio-legalidade. Acesso em 02/09/2017.

. Jurisdição e poder: contribuição para a história dos recursos cíveis. São Paulo: Saraiva, 1987.

VERDE, Giovanni. Las ideologias del processo em um reciente ensayo. In. AROCA, Juan Montero (coord.). "Processo Civil e Ideologia: Un prefacio, una sentencia, dos cartas y quince ensayos". Valencia, Tirant Lo Blanch, 2006.

WAMBIER, Luiz Rodrigues, CORREIA DE ALMEIDA, Flávio Renato e TALAMINI, Eduardo. Curso avançado de processo civil. $9^{\mathrm{a}}$ ed. São Paulo: Revista dos Tribunais, 2007. WAMBIER, Teresa Arruda Alvim. Da liberdade do juiz na concessão de liminares e a tutela antecipatória. In: Aspectos polêmicos da antecipação de tutela. São Paulo: Revista dos Tribunais, 1997.

WATANABE, Kazuo. Acesso à Justiça e Sociedade Moderna. In. GRINOVER, Ada Pellegrini, DINAMARCO, Cândido Rangel e (coord.). "Participação e Processo". Ed. RT, 1991.

YARSHELL, Flávio Luiz. A tutela provisória (cautelar e antecipada) no novo CPC: grandes mudanças?, Disponível em: http://www.cartaforense.com.br/conteudo/colunas/atutela-provisoria-cautelar--e-antecipada-no-novo-cpc--grandes-mudancas-iii/15753. Acesso em: 13/07/2016.

e BONÍCIO, Marcelo José Magalhães. Tutela mandamental nas obrigações de pagamento de quantia. In. ARMELIN, Donaldo (coord.). Tutelas de urgência e cautelares. São Paulo: Saraiva, 2010, pp. 564-571. 
ZANETI JR., Hermes. Democracia e judiciário na re(politização) do direito: notas para o papel dos juízes e do Judiciário em um modelo deliberativo-procedimental de democracia. In. MEDINA, José Miguel Garcia et. al. (Coord.). Os Poderes do Juiz e o Controle das Decisões Judiciais: Estudos em homenagem à Professora Teresa Arruda Alvim Wambier. São Paulo: Revista dos Tribunais, 2008. 